\title{
Mauyen Keane, Love Without Border in War-Torn Europe : An Irishwoman's Story
}

\section{David Shaw}

\section{(2) OpenEdition \\ 1 Journals}

\section{Electronic version}

URL: http://journals.openedition.org/etudesirlandaises/6013

DOI: 10.4000/etudesirlandaises.6013

ISSN: 2259-8863

\section{Publisher}

Presses universitaires de Caen

\section{Printed version}

Date of publication: 18 December 2018

Number of pages: 213-214

ISBN: 978-2-7535-7693-3

ISSN: 0183-973X

\section{Electronic reference}

David Shaw, " Mauyen Keane, Love Without Border in War-Torn Europe : An Irishwoman's Story ", Études irlandaises [Online], 43-2 | 2018, Online since 01 November 2018, connection on 24 September 2020. URL : http://journals.openedition.org/etudesirlandaises/6013; DOI : https://doi.org/10.4000/ etudesirlandaises.6013

\section{(c) (†)(อ)}

Études irlandaises est mise à disposition selon les termes de la Licence Creative Commons Attribution - Pas d'Utilisation Commerciale - Partage dans les Mêmes Conditions 4.0 International. 
nity" (164) To Murphy, though the high degree of self-consciousness Banville exhibits elsewhere is less obvious when he uses the Black persona, the same aesthetic agenda finally prevails all the same, preventing his work from being politically or socially motivated.

To cut a long story short: fiction or art according to Banville - be it crime fiction or high-brow cryptic satirical historiographic novels - doesn't and cannot attempt to render reality faithfully. Neither can it produce meaning. But art has to be significant. As a matter of fact, as Murphy demonstrates, reality is always shaped by our imagining minds. Art allows us to catch a glimpse of this counterintuitive but eternal Banvillean truth: the uncanny precedence of imagination over reality.

This book reads well and will certainly help all aspiring or well-established Banville scholars refine or qualify their analyses. There is no doubt it will come in handy to understand this complex and heavily interwoven body of work created by Banville/Black. It certainly proves to be a useful and up-to-date -not to say indispensable-complement to the previous insightful studies written by Derek Hand, Joseph McMinn, Rüdiger Imhof and others.

Thierry RoBIN

Mauyen Keane ${ }^{1}$, Love Without Border in War-Torn Europe: An Irishwoman's Story, Oxford: The Onslaught Press, 2018, (revised ed. of Hello, Is it All Over? (1984), 110 p., €12.

Love Without Borders is a memoir of multiple stories. It is a war-time romance between an Irish nurse and a German Soldier that crossed borders and transgressed societal norms. It is also a story of emigration and a personal recollection of the Second World War.

Mauyen Keane begins her story with her departure from home. There are some hints about what was being left behind. Her family could afford to keep a 'favourite' horse, unwittingly revealing the family had enough money and access to land to support multiple animals. They already had experience of emigration, her sister had previously left for the 'mission fields'. Keane had been accepted to train as a nurse after leaving school. So the family must have been able to afford for her to stay on at school. Her decision to migrate also uncovers the uncomfortable reality that De Valera was failing to meet his promise to lift the 'doom

1. Mauyen Keane is Irish poet Gabriel Rosenstock's mother. 
of exile'. Keane was impatient and unwilling to put up with the long waiting-list for a place to train in Dublin. The social status of the family is uncovered by her choice of destination: Jersey. Her mother's cousin was a doctor on the Island who had married into a wealthy and influential family. Arrangements were made for her travel to Jersey and commence her training. She left Athenry in 1936.

Keane's decision to leave Ireland was not a McCourt-like tale of escape from poverty and suffering into exile. ${ }^{2}$ However, the journey on the cattle-boat to Holyhead was something shared by many, regardless of their backgrounds. Upon arrival in St Helier, she was met by her cousin Brendan, who had married into the Langlois family, who were originally from Normandy and can trace their lineage back to the $14^{\text {th }}$ Century. Her early days in Jersey, before entering a world of starched uniforms, collar studs and envelope corners were spent in comfort and sunshine. During time off from her training, she would join the Langlois family on their yacht on holiday to St Malo in Brittany.

Her training as a nurse was run with military precision by the ward nurses and sisters. Keane was not the only Irish nurse in Jersey, she was joined by nurses from Counties Cavan, Down and Tipperary. In common with many in Britain and Jersey, rumours of war were not, at first, given any serious thought. The declaration of war in September 1939 left Keane 'dumbfounded'. It was only when ration books and gas masks were distributed did the gravity of the situation begin to sink in.

Many began to leave Jersey, including some nurses, so that the hospital had to rely on Red Cross nurses to fill the gaps. Panic set in after the fall of Paris it was obvious that the Channel Islands would be next. To the relief of doctors and patients, Keane and three friends decided to stay and were christened the 'Three Musketeers'. Those that decided to stay soon realised that they were 'all in it together'.

Keane's first experience of the German army was the sound of the soldiers boots on the hospital wards. She gives the reader the briefest of insights into her initial reaction to the occupation describing herself as 'politically neutral'. She does not elaborate on this and fails to make it clear if this is just a statement of Ireland's status or her own political beliefs. She paints a picture of an occupying army that was relieved to be away from the Russian front and infers that the large number of German fracture cases in the hospital were self-inflicted to avoid being sent East. Whilst Keane humanises the German soldiers, she somewhat ignores that the fact that choices made in Germany had plunged the world into war. This may have reflected that portion of the Irish population that viewed the war as another British war and none of their concern. Keane would later be remin-

2. F. McCourt, Angela's Ashes: A Memoir of a Childhood (London: Harper Collins, 2012). 
ded that many from Ireland chose to fight against Hitler and after the defeat of Germany, she would be grateful for the assistance and care shown by Irish soldiers serving with the British army.

In 1942, Keane began a romance with a German Doctor 'Dieter', another who was in uniform not by choice and who was always glad to hide it. Her romance with Dieter received a mixed reaction from her friends. All were aware just how unpopular this romance would have been with some on the island. When Dieter had to go back to Germany to complete his final examinations to become a doctor, despite the news of continuous British and American air-raids over Germany, Keane was determined to follow him.

Although Keane comments on the deprivations suffered by the population of Jersey, it is only when she travels through France to meet Dieter in Germany that she offers the reader a glimpse of her emotions as she experiences the consequences of the war on the French. Whilst in France she learned of forced labour, ruined cities and the ever-increasing death toll. On her way to Jena to meet Dieter, she had to stop in Paris and found 'a lonely and hungry city' that was far from the glamour of the Belle Époque. Finally, after a traumatic train journey from Paris to Jena, she was reunited with Dieter.

The grim reality of the war in Germany soon became apparent as she registered for a ration book and was sharply told 'No Work, No Ration'. She gained employment in a woman's clinic and after each shift, spent the rest of the day in food queues. This was to be her life as a good 'scrubbed' Hausfrau. Before they could get official permission to marry, the Nazi regime intruded into their new life. In 1935 the Law for the Protection of German Blood and Honour had been passed and anyone who did not meet the Aryan ideal would not be allowed to marry a German. ${ }^{3}$ They had to send photographs to a race doctor to ensure the authorities that she was not Jewish. The reply from the Race Doctor was that Keane looked 'slightly Jewish', they were refused permission to marry but Keane could stay in Germany. They were married in secret by a sympathetic priest.

As the bombing increased and the war got closer to Jena, Keane had their first child. By 1945 German refugees from other cities were pouring into Jena. Fear and panic eventually appeared. The driver of these emotions was the advancing Russian Army. Keane and Dieter made plans to escape being trapped in the Soviet Zone.

Having made it to Hamburg, the grind of waiting in line for rations continued. The rations were now so low that people were dying of malnutrition and they had to resort to the black-market, but even the black-market dried up. The spectre of hunger and starvation stalked the family. The decision was made to try 3. M. Burleigh, The Third Reich: A New History (London: Macmillan, 2000), pp. 294-298. 
to attempt to get to Ireland. But Germans were not allowed to leave. They were lucky though when they met a Dublin man who was a sergeant in the British Army. He came to their aid and provide food and took letters home to Ireland with him on leave. Further help was provided by an Irish nurse who was a Major in the British Army, who arrived with food that they had not seen in a long time.

One morning in November 1947 the news they had been waiting for arrived, Dieter had permission to leave for Ireland. In Ireland, Lord Killanin, who had been a major in the British Army and took part in the Normandy Landings took up the case. Also taking up their plight was Lord Pakenham, later to become Lord Longford and would become a controversial figure in British politics. In December 1947, Keane, Dieter and their children finally arrived in Ireland.

Keane would often wonder why she chose to stay on Jersey. Her decision to remain in Jersey was courageous but her relationship with Dieter raises the potentially ugly and controversial theme of collaboration. Keane humanises the German population and the effect of war on civilians. However, Keane offers no opinion or commentary on the barbarity of the Nazi regime after describing her visit to the 'Race Doctor'. Keane's short biography is an intimate story of emigration and of a potential contravention of war-time sensibilities.

David SHAW 